\title{
The surveys: nexus between industry and academia
}

\author{
J. Fernández, M. Cruells, N. Escaja, J.A. Garrido, J. Giménez, M. Llauradó, A. Roca, L. \\ Rodríguez, M.Ll. Sagristà, C. Navarro, J.O. Bernad, C. Escobar, N. López \\ Quality Committee, Faculty of Chemistry. Universitat de Barcelona. \\ C/ Martí i Franquès, 1. 08028 Barcelona. Spain. \\ Phone+34934021776. E-mail: javier.fernandez@ub.edu
}

\begin{abstract}
Analysis and improvement processes are key aspects in any quality management system and they have to be applied on the quality management systems that have all degrees currently taught at Spanish Universities. In this way, surveys can be an important tool. For this reason, the Faculty of Chemistry of the Universitat de Barcelona prepared a survey for chemical and pharmaceutical companies to identify the type of training that is required for students. The survey has questions related to the laboratory operations, chemical processes, calculation methods, management systems of quality, environment and safety, general management information, etc. The items are related to the formation given to the students in the Faculty. The scores obtained (minimum 1, maximum 4) are between 2 and 3 in all the items, both the required knowledge as to the skills demonstrated by students. This means a good agreement between the formation achieved by the students and the expectations of the industries. However, these results also show that the training of students can still be improved.
\end{abstract}

Keywords: Surveys; Skills; Quality management; Continuous improvement

\section{Introduction}

As is known, all spanish degrees should have implemented a quality management system (Real Decreto 1393/2007; Real Decreto 861/2010). Therefore, this is the case of the Faculty of Chemistry of the Universitat de Barcelona, which has implemented a quality management system (QMS) for the three degrees taught: Chemistry, Chemical Engineering and Materials Engineering.

Within any QMS, one of the basic tools are the processes of analysis and improvement (Companyó and Ríos, 2002), which are the key element to detect possible weaknesses in the system and, from there, the necessary corrections can be made to modify the defective items, into the process of continuous improvement. Corrective and preventive actions, audits, indicators and surveys are among the tools of analysis and improvement processes.

The Quality Committee of the Faculty of Chemistry is working for several years in the improvement of the quality of laboratories teaching in degrees developed in the Faculty. In their tasks the students have a high volume of purely experimental subjects or combined with theory. In this case one of the main tasks is to obtain the best training process in laboratories in the corresponding studies.

In this way and even before the implementation of new degrees, in 2007, taking advantage of the passage from the old to new degrees according to Bologna, the Quality Committee (QC) of the Faculty of Chemistry of the Universitat de Barcelona conducted a survey. This survey was sent to chemistry and pharmaceutical industries to know what the companies expect of new graduates. The survey was very successful and valuable conclusions were obtained for the development of students curricula in the new degrees (Companyó et al. 2008; Sainz et al. 2008). In relation to the work in the laboratory, the opinion of people from the companies was very varied regarding the utility that the work in laboratories can have in the development of the professional activity, and this opinion was related with the sector of activity typical of each company. Additionally, 
there was a high unanimity in relation to the need that the students have knowledge on management of the information and of the chemical documentation, management of the quality, environmental and safety, planning of the work and management of the time. The information facilitated by the companies through the survey was very useful in the design and application of the new degrees of the Faculty of Chemistry: Chemistry, Chemical Engineering and Engineering of Materials.

As an example, in the degree of Chemistry a course on Quality and Prevention has introduced, the subject of Chemical Documentation has promoted, and also has been included a specific section on safety, quality and environmental management in the presentation of any experimental subject. It has also incorporated a subject on Project Management to perform before or during the development of the degree final work. In surveys carried out to the students at the end of each stay in laboratories, in addition to matters related to the topic of the subject itself, other aspects of safety, environment and quality work performed are asked to them.

In the same way, and given the restructuring that seems looming again in degrees, from the QC, and seven years later (2014), it has been decided to prepare a new survey for companies to see again what the state of the art is regarding the knowledge and skills that should have future graduates in chemistry, chemical engineering and materials engineering. The survey has been passed to companies of different types in the chemical and pharmaceutical sector industry and, in this work, a summary of the main results obtained is shown.

\section{Results and Discussion}

\section{Results of the survey}

Survey was addressed to the following sector companies: Basic Chemistry, 30\%; Chemistry of Health, Animal and Vegetal, 33,3\%; Chemistry for Industry and Final Consumption, 36,7\%. Figure 1 shows the distribution of the companies classified with respect to the number of workers.

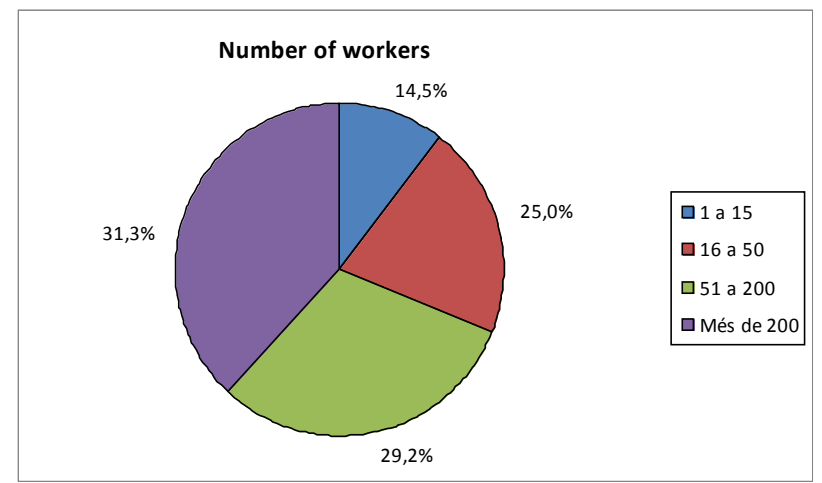

Figure 1. Percentage of companies, based on the number of workers.

Nine sections form the survey: 1) Laboratory operations (3 items). 2) Measurement and characterization techniques (10 items). 3) Chemical processes: pilot plant and industry (6 items). 4) Calculation methods and data processing (5 items). 5) Management of information and documentation (6 items). 6) Quality management (8 items). 7) 
Environmental management (5 items). 8) Safety and health (5 items). 9) Other (3 items): basic knowledge on economy, work planning, time management.

At the end of each section, the survey's respondents can evaluate the level of competences that graduates are on the subjects concerning this section.

Each question was evaluated between 1 and 4, with the following score: 1, not important; 2, unimportant; 3, important; 4, very important.

The average scores obtained in each item were the following:

- 1) Laboratory operations: 2.88

- 2) Measurement and characterization techniques: 2.33

- 3) Chemical processes: pilot plant and industry: 2.51

- 4) Calculation methods and data processing: 2.57

- 5) Management of information and documentation: 3.11

- 6) Quality management: 3.11

- 7) Environmental management: 2.53

- 8) Safety and health: 3.17

- Other (basic knowledge on economy, work planning, time management): 2.86.

As it can be observed, all the sections of the survey have been evaluated between 2 and 3. However, the aspects related to management (information, documentation, safety, quality, time, etc.) seem to be more important for industries.

An important data to be considered is the evaluation of the competences that graduates have in each section. This evaluation is made also by the industries. Results are shown in Figure 2. The sections appearing in the figure are the same indicated in the last paragraph. Results are all them between 2 and 3 showing that graduates can usually meet the expectations of companies.

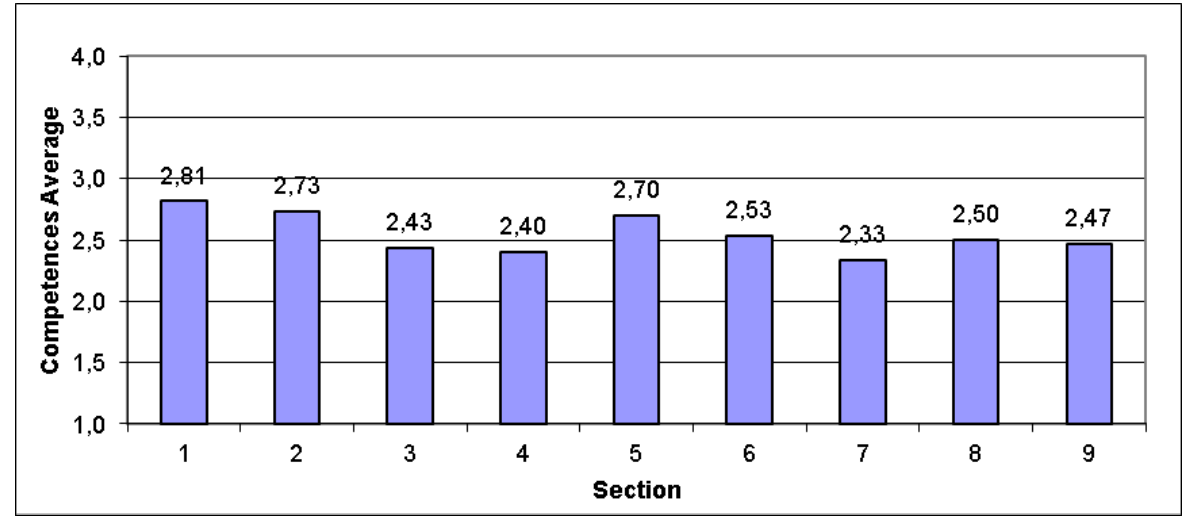

Figure 2. Competences showed by the graduates in each item.

\section{Some remarks}

It is not easy to make an overall assessment of the survey results, because companies answering the survey represent diverse activities, and therefore with very different interests. Moreover, the sections of the survey also covered quite different capacities 
on several levels. However, as commented before, the survey revealed that companies are very interested in that future professionals be fluent in skills related to management of information, quality management, environmental management, safety, work planning and time management. These results are not surprising, because all these issues are, today, of great interest to the industry and, most particularly, for the chemical industry.

For instance, concerning the results obtained in section 5 of the survey, sometimes it is not easy to find a structured documentation on a given subject. Hence companies valued to have people prepared in the management of information, who can go quickly and certainty to the most appropriate sources of information, finding the elements needed to develop the task has been entrusted to them.

Referring to the analysis of results and in the fields of chemistry, chemical engineering and materials engineering, companies need people with a critical view. Thus, they can well interpret the data from production or from the departments of research and development. This is a key step to decide on changes or improvements in production processes that lead to obtaining a higher quality product or raw material savings.

Currently, the quality management is a concern and a goal for companies. Thus, it is not surprising that items related to section 6 of the survey (quality management) are highly evaluated by the polled companies. Obviously, the implementation of a quality management system assures an improvement in production and guarantees the quality of the final product and, moreover, gives to the companies a distinctive and positive marketing element relative to industry peers. It is therefore clear that companies assess positively our students aware of these issues.

Section related to safety (section 8) is also very considered by industries. The reasons are obvious, because they are companies related to the chemical industry and, therefore, they use potentially dangerous substances and work in conditions that can also involve certain risks: high temperature, high pressure, etc. In addition, laws are very restrictive for this industry. In addition, safety is clearly also an issue for the future since it is expected that the regulations in this regard will be increasingly restrictive and, therefore, companies are increasingly forced into depth on these issues.

Finally, companies are very interested in work planning and time management (section 9 of the survey). These last two issues go well linked and are vital for good job performance. In addition, current degrees are focussed on the student's work. Thus, all the competences related to the improving of work planning and time use have to be strengthened.

\section{Improving our degrees from surveys results}

After the first survey (2007) when the new degrees were introduced in our Faculty, some actions were taken according to the companies answers. Thus a course on Quality and Prevention was introduced in the new degree on Chemistry. Concerning the degree on Chemical Engineering, the course related to industrial safety and health was maintained. In addition, in the courses on laboratory training, the aspects related to quality and safety were widely remarked.

It seems that these actions had a positive impact on the students training and, according to the companies' answers, the competences showed by the graduates are satisfactory, as shown in Figure 2. As commented before, the scores for all questions are between 2 and 3 . Thus, the task made seems to give positive results. 
However, we still have further to go in these aspects and more work is needed, including the awareness task of professors on the importance of these subjects. It has to be said that this is not an easy task and efforts have to be made in this way.

Obviously, all needs of the companies cannot be satisfied but these ones considered reasonably interesting for the students training have to be fulfilled as possible. As commented before, some subjects are considered as minor subjects for part of professors and this means an added obstacle

Looking to the future, the new Spanish legislation (Real Decreto 43/2015) opens the possibility to new degrees. Thus, it can be again other opportunity to introduce in a more large extension the items considered important by the industries, if possible.

In any case, this contact university - companies seems a very interesting way for the improvement of the students training and for the updating and adjustment of degrees to the necessities and requests of industries.

Summarizing, it should also be noted that the survey highlights the need for students to acquire skills and competences in the subjects mentioned above. Therefore, it stresses the idea that students have to acquire knowledge but they have also to be able to assimilate and apply. As it is well known, this has been a turning point in the degrees, which have to ensure that students acquire a range of skills and abilities necessary for further professional activity.

\section{Conclusions}

Surveys have proven to be a good tool for getting feedback from companies. From surveys, it is possible to know what is the knowledge, abilities, skills and competences that companies demand to the graduates. In our degrees these results are taken into account and applied in a continuous improvement of the degrees of Chemistry, Chemical Engineering and Materials Engineering.

\section{References}

Compañó, R. \& Ríos, A. (2002). Garantía de la calidad en los laboratorios analíticos. Madrid: Síntesis.

Companyó, R., Cruells, M., Garrido, J.A., Giménez, J., Granell, J., Llauradó, M., Mallol, J., Navarro, C., Pérez, I., Sainz, D., Urpí, F., Vallés, A., Bernad J.O. \& A. Prades, A. (2008). Las encuestas a las empresas: una fuente de información en el desarrollo de las competencias de los estudiantes. El cambio en la cultura docente universitaria - Contenidos de las conferencias y comunicaciones del V CIDUI, (formato electrónico). ISBN: 978-84-8458-286-1. Lleida.

Real Decreto 1393/2007, de 29 de octubre, por el que se establece la ordenación de las enseñanzas universitarias oficiales.

Real Decreto 861/2010, de 2 de julio, por el que se modifica el Real Decreto 1393/2007, de 29 de octubre, por el que se establece la ordenación de las enseñanzas universitarias oficiales.

Real Decreto 43/2015, de 2 de febrero, por el que se modifica el Real Decreto 1393/2007, de 29 de octubre, por el que se establece la ordenación de las 
enseñanzas universitarias oficiales, y el Real Decreto 99/2011, de 28 de enero, por el que se regulan las enseñanzas oficiales de doctorado.

Sainz, D., Companyó, R., Cruells, M., Garrido, J.A., Giménez, J., Granell, J., Llauradó, M., Mallol, J., Navarro, C., Pérez, I., Urpí F. \& Prades, A. (2008). La opinión de las empresas sobre la enseñanza práctica: una fuente de información en el desarrollo de las competencias de los estudiantes. Libro de Actas de la III Reunión de Innovación Docente en Química (INDOQUIM 2008). p. 181-182. ISBN: 97884-9828-204-7. D.L.: CA 203/08. Cádiz: Servicio de Publicaciones de la UCA. 